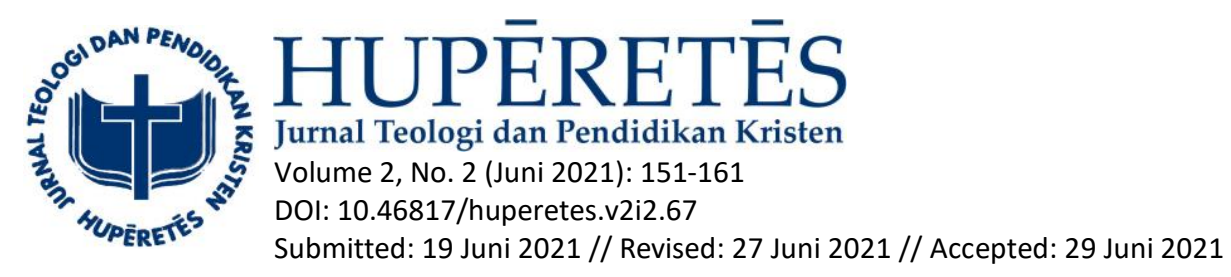

\title{
Ciri Khas Eskatologi Injil Lukas
}

\author{
Agus Prasetyo \\ Sekolah Tinggi Teologi Lutheran Yogyakarta \\ Korepondensi: aghussttl@gmail.com
}

\begin{abstract}
Abstrak: Injil Lukas merupakan injil yang lengkap dalam proses penyusunan. Dalam materi yang disusun, penelitian ini menuturkan topik eskatologi yang merupakan topik kontroversial pada masa itu. Bahkan kontroversi tafsir eskatologis terus berlangsung sepanjang abad. Tulisan ini bertujuan mengelaborasi pemikiran-pemikiran eskatologis menurut injil Lukas. Tulisan ini meneliti penuturan-penuturan Lukas berhubungan dengan zaman akhir. Metode penelitian yang dilakukan peneliti adalah dengan melakukan analisa tematik terhadap narasi injil Lukas berkenaan dengan eskatologi. Secara rinci pelaksanaan penelitian dilakukan dengan tahapan sebagai berikut; tahapan pertama adalah melihat tujuan teologi Lukas, sehingga dengan melihat tujuan Lukas, maka gambaran tentang eskatologi yang dilaporkan Lukas menjadi lebih jelas. Selain meneliti bukti tekstual dari injil Lukas, tulisan ini juga mempertimbangkan pemikiran dari para ahli Perjanjian Baru guna mempertajam tafsiran yang ditemukan. Hasilnya, prinsip perkembangan pewahyuan menjadi landasan dalam pemikiran eskatologi Lukas. Kekhasan Eskatologi Lukas dapat dipahami dalam tiga aspek yaitu Janji eskatologis, awal penggenapan janji dan pengharapan kesempurnaan janji. Janji eskatologis menjadi dasar dari sebuah pengharapan yang pasti bagi orang percaya di sepanjang abad.
\end{abstract}

Kata kunci: Lukas, eskatologi, janji

Abstract: The Gospel of Luke is a complete gospel in the process of compilation. In the material compiled, this research describes the topic of eschatology which was a controversial topic at that time. Even the controversy over eschatological interpretation has continued throughout the centuries. This paper aims to elaborate eschatological thoughts according to Luke's gospel. This paper examines Luke's narratives related to the last days. The research method used by the researcher is to conduct a thematic analysis of Luke's gospel narrative regarding eschatology. In detail, the implementation of the research was carried out in the following stages; the first stage is to look at the purpose of Luke's theology, so that by looking at Luke's goals, the description of the eschatology that Luke reports becomes clearer. In addition to examining the textual evidence of Luke's gospel, this paper also considers the thoughts of New Testament scholars in order to sharpen the interpretations found. As a result, the principle of the development of revelation became the foundation of Luke's eschatological thinking. The peculiarities of Luke's Eschatology can be understood in three aspects, namely the eschatological promise, the beginning of the fulfillment of the promise and the hope of the perfection of the promise. The eschatological promise forms the basis of a sure hope for believers throughout the centuries.

Keywords: Luke, eschatology, covenant 


\section{PENDAHULUAN}

Usaha pembahasan tema eskatologi selalu menarik. Selain keragaman hasil interpretasi dan kompleksitas diskusi yang terkandung didalamnya, tema eskatologi tidak jarang menyisakan "pekerjaan rumah" untuk diselesaikan. Salah satunya adalah mencirikan kekhasan eskatologi dari masing-masing kitab. Meskipun sumber informasi eskatologi dapat dipelajari dari kitab Nabi-nabi hingga Wahyu, namun pembahasan kali ini akan dikhususkan dari sumber laporan Lukas dan dibandingkan dengan laporan Matius dan Markus. Tujuan pembahasannya bukan untuk menentukan atau mendukung posisi eskatologi tertentu, namun untuk mencermati kekhasan laporan Lukas khususnya terhadap tema eskatologi.

Seringkali, dalam menafsirkan topik eskatologi para penafsir merujuk pada Injil Matius karena penyusunan materi Injil Matius memuat teks-teks non mesianik yang dipakai untuk menggambarkan keadaan akhir zaman yang relevan dengan orang Yahudi. ${ }^{1}$ Tidak banyak ahli teologi sistematika, khususnya mereka yang berkonsentrasi pada bidang eskatologi menaruh minat mereka menyelidiki eskatologi dalam Injil Lukas. Asumsinya adalah Injil Lukas memiliki kesatuan dengan Kisah Para Rasul yang merupakan karya sastra narasi. ${ }^{2}$ Dalam pengamatan yang dilakukan ditemukan fakta bahwa dalam kepenulisan Injil Lukas, ada tema-tema tertentu yang disematkan oleh Lukas yang bermanfaat untuk mengajarkan doktrindoktrin tertentu kepada gereja, salah satunya eskatologi. Oleh karena itu, penyelidikan pada artikel ini dilakukan dengan cara mengidentifikasi tema-tema eskatologis guna membangun pokok-pokok ajaran eskatologi menurut ciri khas Injil Lukas.

Capaian penyelidikan tentang kekhasan eskatologi Lukas dalam penelitian ini dilakukan dengan tahapan sebagai berikut; tahapan pertama adalah melihat tujuan teologi Lukas,

\footnotetext{
${ }^{1}$ Bruce Henning, Matthew's Non-Messianic Mapping of Messianic Texts (BRILL, 2021), https://brill.com/view/ title/58861.

${ }^{2}$ Charles H. Talbert, Reading Act: (Macon: Smyth \& Helwys Publishing, 2005), xiv.
}

sehingga dengan melihat tujuan Lukas, maka gambaran tentang eskatologi yang dilaporkan Lukas menjadi lebih jelas, sebab diasumsikan bahwa kekhasan eskatologi sangat dipengaruhi tujuan penulisan kitab. Tahapan kedua adalah mencermati paralelisme dan perbedaan antara laporan Lukas, Matius dan Markus. Tujuan dari pembandingan ini untuk melihat ucapan-ucapan kunci yang menyumbang gagasan terhadap asumsi adanya kekhasan ini. Tahap ketiga adalah dengan menguraikan dimensi eskatologi dari sudut pandang laporan Lukas sesuai dengan kekhasan dalam ucapan eskatologi yang terlihat dalam Injil Lukas, sekaligus juga membandingkan dimensi eskatologi tersebut dengan Injil Sinoptik lainnya.

\section{METODE}

Metode penelitian yang digunakan dalam penelitian ini adalah penelitian teologi yang menekankan pada penggalian nas-nas Alkitab berdasarkan tema-tema yang dikembangkan oleh penulis kitab. Penelitian ini merupakan penelitian teologis yang menekankan pada penggalian dokumen keagamaan, berupa Alkitab sebagai sumber utama dalam penelitian ini. Dalam proses penelitian, tulisan ini akan memanfaatkan beberapa teori para ahli dalam menjabarkan konsep eskatologi menurut Injil Lukas. Beberapa pakar Perjanjian Baru, seperti Darrel C. Bock, Leon Morris, George Eldon Ladd dan sebagainya merupakan pakar yang memiliki reputasi akademik dan penelitian Perjanjian Baru. Tulisan ini akan meneliti apa pemikiran mereka tentang konsep eskatologi dalam Injil Lukas.

Beberapa prosedur yang akan dilaksanakan dalam menjalankan penelitian adalah sebagai berikut: Pertama, melakukan observasi terhadap berbagai nas dalam Injil Lukas yang memuat topik eskatologi. Kedua, meneliti pemikiran teologis Lukas mengenai akhir zaman. Injil Lukas merupakan injil yang istimewa karena memuat dari berbagai sumber (Luk. 1:3-4). Asumsinya adalah Lukas telah menyarikan berbagai macam tulisan yang dianggap valid, kemudian menyusun suatu sintesa. Jadi, pemikiran Lukas tentang akhir zaman 
(eskatologi) telah melalui berbagai macam pertimbangan oleh sang penulis, kemudian menyimpulkan dalam tulisannya. Ketiga, meneliti berbagai pemikiran dari para ahli yang dipakai untuk mempertajam teori yang ditemukan

\section{PEMBAHASAN}

Penjabaran mengenai kekhasan Eskatologi Lukas tidak bisa dilepaskan dari tujuan teologi kitab tersebut, sebab penulis berasumsi bahwa tujuan penulisan akan mewarnai laporan eskatologi yang pada gilirannya akan menyumbangkan kekhasan kitab itu sendiri. Salah satu cara untuk melihat tujuan teologis Injil Lukas adalah melalui pengamatan terhadap banyaknya narasi yang melibatkan orang Yahudi maupun non Yahudi yang ditampilkan dalam laporan Lukas. Laporan tentang orang Yahudi (1:33: 2:10) orang Samaria (pada pasal 9:51, 56, 10: 30-37 17:11-19), orang-orang non Yahudi (2:32: 3:6; 38:4-25-27; 7:9: 10:1; 24:47), pemungut cukai, orang berdosa dan orang tersingkir, orang terhormat, orang miskin dan kaya, serta keterlibatan perempuan dan pria, semuanya ini mengindikasikan maksud laporan Lukas adalah menekankan universalisme.

Pengamatan mengenai tujuan teologi kitab Lukas telah dilakukan para sarjana terdahulu. Paul Enns, memperhatikan laporan Lukas mengenai garis keturunan Yesus dengan Adam dan dari sana ia melihat penekanan kosmopolitas yang menekankan universalitas Injil dan bahwa Yesus adalah penebus dunia. ${ }^{3}$ Selanjutnya, Barclay mengamati kontribusi Lukas yang telah menulis 27\% Perjanjian Baru dan keunikannya dalam memberikan biografi tentang kehidupan Yesus. Dari pengamatan individu dan tulisan Lukas, diperoleh beberapa pengertian bahwa Lukas dapat menceritakan kasih Yesus kepada orang lain dari pengetahuan tentang diriNya, meskipun pengetahuan itu berasal dari iman bukan dari penglihatan. ${ }^{4}$ Dengan cara yang berbeda, Bock melihat beban

3Paul Enss, The Moody Handbook of Theology (Malang: SAAT, 2004), 199.

${ }^{4}$ William Barclay, Introduction to the Three Gospels (Philadelphia: The Wesminster Press, 1975), 186. utama Lukas adalah menjelaskan rencana Allah yang sedang menggenapi janjiNya. Namun, universalitas dilihat Bock sebagai bagian dari rencana Allah menggenapi janjinya, yaitu janji bagi bangsa Yahudi dan bangsa-bangsa lain. Menurutnya, Lukas menekankan bahwa apa yang diberikan Yesus disediakan bagi semua orang. ${ }^{5}$ Di sisi lain, Leon Morris, meskipun meyakini teologi Lukas mempunyai banyak aspek, dan ia memulai pemikirannya dengan keyakinan bahwa Allah adalah Allah yang mahakuasa yang mampu melakukan rencanaNya sampai tuntas dan Ia memang melaksanakannya, namun dalam penjelasannya, ia mengamati universalime Lukas dengan kajian yang lebih komprehensip. Dalam kesimpulannya ia menjelaskan bahwa universalisme Injil tidaklah terbatas pada lingkup nasional dan geografis saja. Lingkup aktivitas Kristus yang menyelamatkan itu juga disampaikan kepada orang yang dalam hal tertentu dirampas hak-haknya. ${ }^{6}$

Memang jika dibandingkan dengan Matius, Lukas justru mengawali dan mengakhiri laporannya dengan menyebut kota Yerusalem. Jadi tidak bisa diragukan bahwa Lukas menekankan peranan Yerusalem dan segala sesuatu yang bersifat Yahudi sebagai dasar agama Kristen. Namun universalitas Lukas lagi-lagi ditunjukkan dengan pandangannya yang luas, dimana bagi Lukas semua bangsa termasuk dalam lingkup keselamatan. Kutipan Yesaya 40 yang dikutip hingga kalimat "semua orang akan melihat keselamatan yang dari Tuhan" (3:4-6) membuktikan keseriusan Lukas dalam menyampaikan laporan tentang universalitas keselamatan. Catatan universal ini muncul juga dalam Lukas 24:47, dimana pesan dari komunitas yang baru adalah pemberitaan tentang pertobatan kepada semua bangsa. Pesan ini telah dinubuatkan oleh Perjanjian Lama. Melalui keselamatan yang diperluas sampai ke bangsa-bangsa lain, janji-janji Allah tentang Mesias pada awalnya diwujudkan.

${ }^{5}$ Darrell L. Bock, "Teologi Lukas-Kisah Para Rasul," in A Biblical Theology of the New Testament, ed. Darrell L. Bock and Zuck. Roy B. (Malang: Gandum Mas, 2011), 133.

${ }^{6}$ Leon Morris, Teologi Perjanjian Baru (Malang: Gandum Mas, 2001), 190-281. 
Dengan memperhatikan tujuan teologi Lukas ini, maka tentu saja pemahaman mengenai kekhasan eskatologi Lukas akan berada di atas fondasi tujuan utama ini. Oleh karena itu, setiap rujukan laporan Lukas terkait eskatologi perlu dicocokan dengan gagasan tentang universalitas janji Allah ini.

Kekhasan Eskatologi Lukas dapat dipahami dalam tiga aspek yaitu janji eskatologis, awal penggenapan janji dan pengharapan kesempurnaan janji. Bock menguraikan hal ini dalam tiga kata kunci yaitu aspek "peralihan, aspek "sudah" (zaman gereja) dan aspek "belum" (kedatangan Kristus kembali). ${ }^{?}$

\section{Janji Eskatologis}

Keunikan eskatologi Lukas mulai nampak dalam suguhan laporan tentang janji Allah dalam Perjanjian Lama. Sejak pasal 1:32, Lukas telah memperkenalkan kekhasan eskatologinya dalam aspek janji. Dikatakan bahwa Ia akan menjadi besar dan akan disebut Anak Allah yang maha Tinggi. Dan Tuhan Allah akan mengaruniakan kepadaNya takhta Daud bapa leluhurnya. Ayat ini menjelaskan tentang janji mengenai pemerintahan Yesus atas bangsa bahkan ayat selanjutnya menjelaskan bahwa anak yang dijanjikan itu akan menjadi anak yang paling tinggi kedudukannya, yaitu akan menjadi Anak Allah. KerajaanNya tidak akan pernah mengenal akhir. Kekhasan Lukas dalam mewarnai aspek janji pada pengajaran eskatologinya juga terlihat dalam nyanyian pujian Zakharia pasal 1:68-74, dimana dalam perikop itu Lukas mengenalkan janji keselamatan bagi Israel dimasa mendatang.

Melalui Zakharia yang berbicara tentang keselamatan yang akan datang melalui Yesus Kristus sebagai suatu fakta yang sudah dinubuatkan dan akan menjadi kenyataan yang digenapi, Lukas seolah ingin menyadarkan posisi pembaca pada kurun waktu zaman akhir dari Alkitab Perjanjian Lama, yaitu zaman perjanjian. Dengan adanya Lukas 2 maka setiap orang memasuki kurun zaman Alkitab Perjanjian Baru, yaitu zaman penggenapan dari perjanjian itu.

${ }^{7}$ Bock, “Teologi Lukas-Kisah Para Rasul,” 185.

\section{Awal Penggenapan Janji}

Setelah mengawali dimensi eskatologis dengan laporan tentang "janji," maka Lukas memperlihatkan kekhasannya dengan menunjukkan struktur awal dimulainya penggenapan janji tersebut. Jika dicermati, awal penggenapan janji ini dapat disaksikan melalui peran Yohanes, Roh Kudus dan Berita Penghukuman.

\section{Melalui Peran Yohanes Pembaptis}

Lukas secara tegas memunculkan tokoh pendahulu yaitu Yohanes pembaptis dalam permulaan pelaporan Injilnya. Bahkan pelaporan tentang kelahiran Yohanes mendahului catatan tentang kelahiran pribadi sentral yaitu Yesus. Tidak mengherankan karena dalam catatan Lukas, peran Yohanes sebagai pendahulu memiliki peranan penting dalam eskatologi Lukas yaitu sebagai pemeran dalam peralihan penggenapan. Banyak penafsir yang mengaitkan ucapan Yohanes pada penggenapan Janji. G.E. Ladd melihat pentingnya pelayanan Yohanes pembaptis dari latar belakang historis pada masa Yohanes itu. Ia menjelaskan bahwa Allah yang menurut pemikiran Yahudi yang mutakhir, selama berabad-abad tidak aktif, sekarang berinisiatif untuk memenuhi janji para nabi dan menggenapi kerajaan itu. Akhirnya Ia telah mengangkat seorang nabi untuk menyatakan kehendak Ilahinya. ${ }^{8}$ Pentingnya peran Yohanes nampak dalam pasal 7:19; "ia (Yohanes) memanggil dua orang dari antaranya dan menyuruh mereka bertanya kepada Tuhan: "Engkaukah yang akan datang itu atau haruskah kami menantikan seorang lain?"

Lukas dalam laporannya mencatat bahwa pertanyaan yang diajukan Yohanes melalui murid-muridnya memberikan kepada Yesus kesempatan untuk membeberkan perananNya yang sesungguhnya sebagai Mesias, yaitu sebagai hamba Allah. Yesus telah melakukan hal ini di dalam rumah ibadat di kota Nazaret (4:18-19) sambil mengutip kata-kata yang diucapkan oleh

${ }^{8}$ George E. Ladd, Teologi Perjanjian Baru (Bandung: Kalam Hidup, 2017), 42-43. 
nabi Yesaya 61: 1-2. Sekarang Yesus kembali mengutip kata-kata ini dan memperlihatkan bagaimana Ia sedang memenuhi isi kata-kata itu. Ia mengutus kembali murid-murid itu kepada Yohanes sambil memerintahkan kepada mereka untuk melaporkan bahwa mereka telah mendengar dan telah melihat. Yesus menunjuk kepada mujizat-mujizat yang telah Ia lakukan, termasuk juga di dalamnya peristiwa membangkitkan orang mati di kota Nain, sebagai bukti bahwa Ia adalah satu-satunya Juruselamat yang telah dijanjikan di dalam Alkitab Perjanjian Lama.

Awal penggenapan janji melalui peran Yohanes dicatat secara khas oleh Lukas dalam peristiwa pembaptisan Yohanes. Ladd dalam penjelasannya mencoba membandingkan antara baptisan Yohanes dengan baptisan Proselit. Hasilnya, ia menemukan perbedaan yang jelas antara dua upacara baptisan itu. Baptisan Yohanes bersifat eskatologis, yakni alasan dilakukannya ialah menyiapkan manusia untuk kerajaan yang akan datang. " Peran Yohanes dalam laporan Lukas tentu memberikan makna baru kepada upacara baptisan selam dalam mengajak manusia bertobat dalam pandangan Kerajaan yang akan datang. Yohanes pembaptis meringkas harapan Perjanjian Lama dan mengumumkan apa yang akan dibawa oleh Ia yang lebih berkuasa menjanjikan datangnya Roh Kudus. Ini tentu menjadi informasi yang jelas tentang awal penggenapan janji eskatologis dalam kitab Lukas.

\section{Melalui Turunnya Roh Kudus}

Lukas tidak saja secara gamblang
menguraikan peranan Yohanes sebagai
pendahulu bagi awal penggenapan janji
eskatologis, namun juga melalui tulisannya
dalam Kisah Para Rasul pasal 2, turunnya Roh
Kudus pada hari pentakosta menandai awal
penggenapan atas masa yang dijanjikan itu.
Kedatangan Roh Kudus menyempurnakan masa
transisi, artinya mendatangkan penggenapan
awal dari berkat yang dijanjikan bagi mereka
yang mengakui bahwa Yesus adalah Mesias yang
di janjikan. Bock menjelaskan bahwa turunnya

Roh Kudus pada pentakosta, menandai "sudah" datangnya jaman masa yang dijanjikan itu. Kini Yesus berfungsi sebagai Tuhan Mesias yang memberikan berkat-berkat yang dijanjikan dalam Perjanjian Lama dan menganggap semua orang percaya bertanggung jawab untuk merespon Dia. ${ }^{10}$ Dalam tema khusus yang lain, ia juga menjelaskan bahwa pencurahan Roh Kudus menunjukkan bahwa Yesus menggunakan otoritas yang menyelamatkan dan hak-hak istimewa karena memerintah di sisi Allah. Jadi dalam pandangan Lukas, kerajaan itu hadir bukan dalam bentuk akhir tetapi dalam bentuk awal dimana janji-janji tentang hari-hari akhir telah mulai digenapi. ${ }^{11}$ Roh Kudus merupakan unsur penting dalam rencana Allah. Peranan Roh Kudus menandakan dimulainya penggenapan janji Allah. Lukas dalam laporannya menekankan penerimaan Roh Kudus oleh kumpulan orang percaya atau komunitas sebagai tentang awal penggenapan dari perjanjian yang baru. Pencurahan Roh Kudus mewakili datangnya berkat awal penggenapan janji, sebagai tanda dari permulaan jaman baru dalam karya Allah.

\section{Melalui Pesan Pemberita}

Harus diakui, bahwa Matius dan Lukas samasama mencatat berita tentang awal penggenapan janji eskatologis melalui pesan pemberita.

Namun ada kekhasan yang ditunjukkan Lukas dalam paralel berikut ini;

\footnotetext{
${ }^{10}$ Bock, "Teologi Lukas-Kisah Para Rasul,” 107.

${ }^{11}$ Ibid., 107.
} 


\begin{tabular}{|c|c|}
\hline Matius & Lukas \\
\hline $\begin{array}{l}\text { Mat 10:8 } \\
\text { Sembuhkanlah orang } \\
\text { sakit; bangkitkanlah } \\
\text { orang mati; tahirkanlah } \\
\text { orang kusta; usirlah } \\
\text { setan-setan. Kamu telah } \\
\text { memperolehnya dengan } \\
\text { cuma-cuma, karena itu } \\
\text { berikanlah pula dengan } \\
\text { cuma-cuma. }\end{array}$ & $\begin{array}{l}\text { Luk 9:2 Dan Ia mengu- } \\
\text { tus mereka untuk mem- } \\
\text { beritakan Kerajaan } \\
\text { Allah dan untuk } \\
\text { menyembuhkan orang, }\end{array}$ \\
\hline $\begin{array}{l}\text { Mat 10:14 } \\
\text { Dan apabila seorang } \\
\text { tidak menerima kamu } \\
\text { dan tidak mendengar } \\
\text { perkataanmu, keluarlah } \\
\text { dan tinggalkanlah } \\
\text { rumah atau kota itu dan } \\
\text { kebaskanlah debunya } \\
\text { dari kakimu. }\end{array}$ & $\begin{array}{l}\text { Luk 10:11 Juga debu } \\
\text { kotamu yang melekat } \\
\text { pada kaki kami, kami } \\
\text { kebaskan di depanmu; } \\
\text { tetapi ketahuilah ini: } \\
\text { Kerajaan Allah sudah } \\
\text { dekat. }\end{array}$ \\
\hline
\end{tabular}

Awal penggenapan eskatologi dalam kitab Lukas terlihat dari perbedaan yang khas dalam laporan mengenai konsekuensi pemberitaan yang dilakukan para utusan Allah pada konteks mandat pemberitaan. Terlihat bahwa paralel yang ditulis dalam laporan Matius dalam konteks yang sama, tidak menyebutkan kata kerajaan Allah sudah dekat. Meskipun harus diakui, jumlah penyebutan kata kerajaan yang dipakai Matius lebih banyak dibandingkan laporan Lukas. Matius menggunakan istilah kerajaan kurang lebih lima puluh kali dan Lukas hanya menggunakan sebanyak tiga puluh delapan kali. Sementara Markus menyebut sebanyak delapan belas kali. Namun dari dua petunjuk ayat ini terlihat bahwa Lukas memiliki penekanan bahwa urgensi pemberitaan keselamatan ini berimplikasi pada awal penggenapan yaitu penghakiman eskatologi. Pemahaman mengenai kekhasan Lukas dalam ayat ini dapat dilihat dengan memperhatikan beberapa pendapat terdahulu.

Victor H. Prange, menjelaskan bahwa tindakan dengan cara mengebaskan debu yang melekat pada kaki mereka adalah merupakan suatu lambang tentang penghukuman Allah yang akan datang terhadap orang-orang yang menolak amanat anugerah kasih Allah. Meskipun mendapat sambutan baik atau tidak, tetap saja utusan harus mengumumkan bahwa Kerajaan Allah sudah dekat dalam bentuk pribadi Yesus Kristus. ${ }^{12}$ Sedangkan F. F. Bruce melihat ayat ini sebagai bentuk penolakan tanggung jawab lebih lanjut para penginjil setelah mereka menyampaikan pesan itu. ${ }^{13}$

Bock juga memperkuat argumen ini dengan mengatakan bahwa, orang-orang bersalah atas keputusan mereka dalam masa krusial ini, mengakibatkan penghakiman datang "atas" mereka. Kedatangan kerajaan datang terlepas dari tanggapan mereka. Mereka telah terhilang karena penolakan mereka. ${ }^{14}$ Buah pikiran bahwa sejumlah kota-kota akan menolak amanat tentang Kerajaan Allah itu telah mendorong Yesus untuk berbicara terhadap sikap yang keras dan cenderung untuk tidak bertobat. Hal ini mengingatkan penghakiman terhadap Sodom yang mengalami kebinasaan oleh api dan belerang oleh karena keadaannya yang bejat (Kej. 19:24). Walaupun demikian penghakiman terhadap Sodom tidak sebanding dengan penghakiman yang terkesan dalam ayat yang menguraikan penolakan kota-kota terhadap pemberitaan utusan-utusanNya.

Argumentasi ini diperkuat dengan analisa Morris, yang melihat laporan Lukas ketika Ia bercerita tentang Yohanes Pembaptis, yakni tentang "kapak sudah tersedia pada akar pohon" (3:9) dan tentang penampian dan pembakaran debu jerami dalam api yang tak terpadamkan (3:17), pemikiran Lukas terarah pada penghakiman eskatologis. ${ }^{15}$

Kekhasan Lukas dalam menguraikan penghakiman eskatologis bagi penolakan berita kerajaan terlihat juga dari ucapan peringatan yang diucapkan Yesus terhadap kota-kota Korazin, Betsaida dan Kapernaum (Lukas 6:24-26). Kosakata bahasa Yunani untuk "kedalaman" adalah "Hades," yaitu tempat

${ }^{12}$ Victor Prange, The People Bible: Luke (Milwaukee: Northwestern Publising House, 1994), 105.

${ }^{13}$ F.F Bruce, "Lukas," in Tafsiran Alkitab Masa Kini 3, ed. Donald Guthrie (Jakarta: Yayasan Komunikasi Bina Kasih, 2003), 218.

${ }^{14}$ Darrell L. Bock, "Luke," in Baker Exegetical Commentary on the New Testament (Grand Rapids: Baker Books, 1996), 1001.

${ }^{15}$ Morris, Teologi Perjanjian Baru, 303. 
kediaman orang-orang mati dalam bagian tersebut menarik untuk diperhatikan. Awal penggenapan janji dalam pemberitaan penghukuman juga tertulis dalam perumpamaan yang dikisahkan dalam Lukas 13:6-9. F. F. Bruce telah menjelaskan bahwa perumpamaan ini merupakan gambaran sikap Yerusalem yang menolak Tuhan Yesus yang datang membawa pesan Allah. Dan dari sikapnya mengakibatkan kehancuran. ${ }^{16}$

Melalui perbandingan ayat tersebut, ada asumsi bahwa Lukas tegas menyampaikan bahwa penolakan terhadap pemberitaan tersebut akan mendatangkan penghakiman di masa mendatang. Ini merupakan berita dari permulaan penggenapan janji yang ditekankan oleh Lukas.

\section{Pengharapan Kesempurnaan Penggenapan}

Pengharapan akan kesempurnaan penggenapan janji dijelaskan secara terperinci melalui teks-teks Lukas. Pengharapan kesempurnaan itu mulai terlihat dalam Lukas 1:31-35 yang menjelaskan tentang arah pemerintahan Yesus yang akan memerintah semua bangsa secara langsung. Dia akan menggunakan kedaulatannya sebagai hakim atas orang hidup dan orang-orang mati. Selanjutnya, pengharapan kesempurnaan akan dijelaskan dalam dua aspek yaitu Pengharapan kedatangan dan pengharapan dalam pemerintahan yang akan datang.

\section{Pengharapan Kedatangan}

Pengharapan kesempurnaan yang kedua nampak dalam dua pengajaran tentang akhir jaman yaitu 17:22-37 dan 21:5-38. Dari teks- teks itu, ada laporan pararel yang menarik untuk dicermati.
Matius 24:23 Pada waktu itu jika orang berkata kepada kamu: Lihat, Mesias ada di sini, atau Mesias ada di sana, jangan kamu percaya.

Lukas 17:21 juga orang tidak dapat mengatakan: Lihat, ia ada di sini atau ia ada di sana! Sebab sesungguhnya Kerajaan Allah ada di antara kamu."

Lukas 21:8 Jawab-Nya: "Waspadalah, supaya kamu jangan disesatkan. Sebab banyak orang akan datang dengan memakai nama-Ku dan berkata: Akulah Dia, dan: Saatnya sudah dekat. Janganlah kamu mengikuti mereka.

Markus 13:21 Pada waktu itu jika orang berkata kepada kamu: Lihat, Mesias ada di sini, atau: Lihat, Mesias ada di sana, jangan kamu percaya.

Melalui paralelisme ini terlihat laporan Lukas mencatat pernyataan bahwa kerajaan Allah ada "diantara kalian" yang menunjuk kepada individualis maupun kolektif dengan mengacu pada yang hadir (yaitu orang-orang Farisi). Namun "diantara kalian" juga dapat mengacu pada lingkup pengaruh kerajaan, otoritas, atau keefektifannya. ${ }^{17}$

Kemudian, pada ayat 21:8, Lukas mengkhususkan laporannya tentang peringatan munculnya penyesat pada akhir jaman dengan menambahkan kata "saatnya sudah dekat." Sementara terlihat dalam paralelisme di atas bahwa Matius dan Markus tidak mencatatkan tambahan pada laporan ini. Sangat mungkin, laporan Lukas hendak ditekankan pada "masa kedatangan.” Laporan lengkap mengenai tema parousia dalam Lukas terlihat dari pasal 17 dan 21:25-33. Pasal 17:20-37 merupakan laporan tentang kedatangan kerajaan Allah, sedangkan pasal 21:25-33, merupakan perumpamaan tentang kedatangan anak Manusia.

Harus diakui bahwa pembahasan mengenai parousia membutuhkan penelitian yang lebih

${ }^{17}$ Barbara Friberg, Timothy Friberg, and Neva F. Miller, Analytical Lexicon of The New Testament (Grand Rapids: Baker Books, 2000). 
mendalam. Morris mengakui tidak mudah membedakan manakah pernyataan yang mengacu pada parousia dengan pernyataan yang mengacu pada penghancuran Yerusalem. ${ }^{18}$ Pembahasan tentang tema kedatangan juga berbenturan dengan konsep Yudaisme apokaliptis yang memiliki pengharapan yang berbeda-beda. Beberapa penulis menekankan aspek duniawi dan aspek historis kerajaan itu, sedangkan yang lain menekankan aspek yang transendental. Sementara itu, Bock dalam penjelasannya memaparkan masa kedatangan ini dengan dua tema yaitu kesegeraan dan penundaan. ${ }^{19}$ Bock mencermati tema tersebut karena ia melihat laporan dalam pasal 18:8, Yesus berbicara tentang pembenaran segera yang akan datang pada anak-anak Allah, dan pasal 21:32 Yesus berkata bahwa angkatan ini akan melihat janji-janji Allah digenapi. Sedangkan tema penundaan terlihat dari pasal 19:11-27 yaitu ketika Yesus menjelaskan bahwa dalam masa antara kepergian-Nya dan kedatangan-Nya kembali, murid-murid dituntut setia. Demikian juga dalam percakapan di atas bukit Zaitun Lukas 21:8-9.

Lukas dalam laporan tentang kedatangan menekankan beberapa hal. Pertama, Lukas membedakan antara parousia dengan penghancuran Yerusalem. Morris yang berpendapat demikian juga mengamati pasal 21:27-28 dimana Lukas memasukkan ucapannya "pada waktu itu orang akan melihat Anak Manusia datang dalam awan-awan dengan segala kekuasaan dan kemulian-Nya" (21:27) dan ia menambahkan kata-kata yang hanya ada dalam Injilnya yaitu "apabila semuanya itu mulai terjadi bangkitlah dan angkatlah mukamu, sebab penyelamatanmu sudah dekat" $(21: 28) .^{20}$ Pembedaan antara parousia dan penghancuran Yerusalem nampak pada laporan Lukas. Dalam pasal 21:20-24, Lukas menyampaikan khusus mengenai Yerusalem. Prange menjelaskan bahwa perkataan Yesus yang dicatat Lukas tentang nasib celaka yang akan menimpa Yerusalem itu akan dialami sebagai penghukuman atas dosa-dosa

\footnotetext{
${ }^{18}$ Morris, Teologi Perjanjian Baru, 305.

${ }^{19}$ Bock, “Teologi Lukas-Kisah Para Rasul,” 187-188.

${ }^{20}$ Morris, Teologi Perjanjian Baru, 305.
}

penghuninya dan sebagai penggenapan tentang apa yang tertulis di dalam Alkitab Perjanjian Lama. ${ }^{21}$ Pengamatan seperti ini menunjuk kepada Mikha 3:12 dan Yeremia 6:1-8 dan 26:1-9. Referensi ini sebagai contoh-contoh tentang nubuatan-nubuatan bahwa kota orang-orang Yahudi ini akan diinjak-injak oleh orang-orang kafir sampai tiba saatnya, penghukuman akan digenapkan.

Selanjutnya, Lukas mencatat parousia dengan mengalihkan pembicaraan tentang hari kesudahan bagi nasib kota Yerusalem kepada suatu peristiwa yang lebih mengerikan yaitu kesudahan yang bersifat universal. Kesudahan dunia ini akan ditandai oleh pertanda-pertanda yang dahsyat sehingga menyebabkan orang banyak gemetar oleh ketakutan. Benda-benda langit akan berguncang, laut akan bergelora dan mendidih. Dan pada masa itulah Anak Manusia akan datang di dalam suatu awan-awan yang permai yang penuh kuasa dan kemuliaan yang besar. KedatanganNya tidak lagi dalam bentuk suatu rahasia melainkan akan merupakan "seperti halilintar yang menyambar dan memancarkan cahayanya di cakrawala dari satu ujung langit kepada ujung langit yang lainnya" (Luk. 17:24). Inilah konsep parousia yang nampak dalam laporan Lukas.

Setelah memperhatikan laporan Lukas tersebut, maka dapat disimpulkan bahwa Lukas tidak bermaksud memindahkan parousia kepada suatu masa depan yang masih jauh. Tetapi ia menekankan bahwa rencana Allah terdiri atas tahapan-tahapan dan ada peristiwa-peristiwa tertentu yang harus terjadi sebelum Parousia.

\section{Pengharapan Perjamuan}

Pengharapan kesempurnaan selanjutnya, terlihat dari Lukas 22:30 tentang janji Yesus bahwa para rasul akan memerintah atas kedua belas suku Israel, dan juga janji yang menggambarkan tentang pesta perayaan dimeja perjamuan yang menceritakan jaman yang akan datang. Kekhasan Lukas terlihat dalam pararel berikut;

\footnotetext{
${ }^{21}$ Prange, The People Bible: Luke, 229.
} 
Paralel Injil mengenai Perumpamaan tentang Perjamuan

\begin{tabular}{|l|l|}
\hline \multicolumn{1}{|c|}{ Matius 22:1-14 } & \multicolumn{1}{|c|}{ Lukas 14:13-17 } \\
\hline${ }^{1}$ Lalu Yesus berbicara & ${ }^{13}$ Tetapi apabila engkau \\
pula dalam perumpa- & mengadakan perjamuan, \\
maan kepada mereka: & undanglah orang-orang \\
${ }^{2}$ "Hal Kerajaan Sorga & miskin, orang-orang \\
seumpama seorang & cacat, orang-orang \\
raja, yang mengadakan & lumpuh dan orang-orang \\
perjamuan kawin & buta. \\
untuk anaknya. & ${ }^{14}$ Dan engkau akan \\
${ }^{3}$ Ia menyuruh hamba- & berbahagia, karena \\
hambanya memanggil & mereka tidak mempunyai \\
orang-orang yang telah & apa-apa untuk membalas- \\
diundang ke perjamuan & nya kepadamu. Sebab \\
kawin itu, tetapi orang- & engkau akan mendapat \\
orang itu tidak mau & balasnya pada hari \\
datang. & kebangkitan orang-orang \\
'Ia menyuruh pula & benar." \\
hamba-hamba lain, & ${ }^{15}$ Mendengar itu \\
pesannya: Katakanlah & berkatalah seorang dari \\
kepada orang-orang & tamu-tamu itu kepada \\
yang diundang itu: & Yesus: "Berbahagialah \\
Sesungguhnya & orang yang akan dijamu \\
hidangan, telah & dalam Kerajaan Allah." \\
kusediakan, lembu- & ${ }^{16}$ Tetapi Yesus berkata \\
lembu jantan dan & kepadanya: "Ada seorang \\
ternak piaraanku telah & mengadakan perjamuan \\
disembelih; semuanya & besar dan ia \\
telah tersedia, datang- & mengundang banyak \\
lah ke perjamuan & orang. \\
kawin ini .... & \\
\hline
\end{tabular}

Kekhasan eskatologi Lukas juga nampak dalam laporan tentang perumpamaan perjamuan besar dalam khotbah Yesus. Matius dan Lukas sama-sama mencatat perumpamaan ini. Namun dengan melihat perbandingan pararel di atas, terlihat salah satu laporan Lukas tidak ditulis dalam Matius; yaitu perihal perkataan seorang peserta yang mengucapkan kata "berbahagialah orang yang akan dijamu dalam kerajaan Allah" (ayat 14:15). Atas hal tersebut, dapat dilihat bahwa perumpamaan mengenai perjamuan besar disampaikan oleh Yesus sebagai jawaban atas pernyataan seorang peserta perjamuan, sehingga sangat dimungkinkan Lukas memberi kesan eskatologis pada perumpamaan yang dilaporkannya. Alasan atas asumsi ini adalah karena dalam konteks tersebut, Yesus sedang berbicara di salah satu rumah pemimpin dari orang-orang Farisi bersama ahli taurat dan para tamu yang sangat mungkin sebagian besarnya adalah orang Yahudi (14:1-5).

Terkait pengamatan terhadap nas ini, meskipun Morris memaklumi pandangan yang menganggap bahwa perjamuan ini hanyalah titik tolak untuk merefleksikan eskatologi, namun ia mengingatkan bahwa menurut paham Yahudi, perjamuan mesianis merupakan bagian integral dari gambaran tentang eskatologi. Oleh karena itu, laporan Lukas dalam ayat tersebut sangat mungkin terkait dengan pengharapan Perjamuan Mesianis yang sesuai dengan konsep eskatologi orang Yahudi kala itu.

Ucapan kebahagiaan dalam ayat 15 ini juga dilihat John Bond, sebagai reaksi orang Yahudi yang pada umumnya mempercayai bahwa kerajaan Allah akan perkenalkan dengan perjamuan besar. $^{22}$ Ucapan kebahagiaan semacam itu juga tertulis dalam laporan Lukas pada kisah-kisah sebelumnya (Luk. 6:20-22; 11:27-28). Bunyinya mirip sekali dengan katakata yang terdapat di dalam Wahyu 19:9: "Berbahagialah orang yang diundang pada perjamuan makan pesta perkawinan Anak Domba Allah.”

Di sisi lain, Hendriksen berpendapat bahwa penggambaran kebahagiaan eskatologis yang berkaitan dengan kerajaan Allah di bawah simbolisme perjamuan surgawi itu tidak alkitabiah. Alasannya didasarkan pada fakta bahwa Alkitab sering menggambarkan kegembiraan langit dan bumi yang baru seperti tamu yang berkomunikasi satu sama lain dan dengan tuan rumah dalam perjamuan yang luas (Mzm. 23:5; Yes. 25:6; Mat. 8:11, 12; 22:1; 26:29; Mrk 14:25; Why. 3:20; 19:9). ${ }^{23}$ Pandangan ini memang perlu untuk dipertimbangkan. Namun penekanan tentang dimensi eskatologi dalam laporan Lukas tidak terletak pada konsep orang-orang Yahudi akan tetapi, ia menuliskan pernyataan itu untuk

${ }^{22}$ John Bond, The Gospel According to St. Luke (London: Macmillan, 1890), 130.

${ }^{23}$ William Hendriksen and Simon J. Kistemaker, "Exposition of the Gospel According to Luke," in New Testament Commentary (Grand Rapids: Baker Books, 2001), 730. 
merujuk kembali kepada tujuan utama teologinya.

Jika menengok tujuan teologi kitab Lukas, universalitas Lukas ditunjukkan dalam laporan mengenai perjamuan besar ini. Pesan eskatologi yang universal dapat dilihat dari pemaknaan perumpamaan dimana tidak ada seorang manusia pun dapat memasuki Kerajaan Allah tanpa adanya suatu undangan. Universalitasnya adalah bahwa Allah telah menjadikan segala sesuatunya siap dan disampaikan secara luas bagi semua orang sebagai undangan. Mereka yang tetap tinggal di bagian luar saja, mereka yang menolak tawaran yang penuh anugerah itu, hanyalah dapat mempersalahkan diri mereka sendiri.

Prange, dalam analisanya juga melihat bahwa perumpamaan ini memberikan suatu jawaban yang bersifat sebagian saja terhadap pertanyaan yang semula diajukan Yesus apakah hanya sedikit orang atau banyak orang yang akan beroleh keselamatan. ${ }^{24}$ Pernyataan ini merupakan suatu jawaban yang menekankan tentang betapa limpahnya cinta kasih Allah bagi orang-orang berdosa. Akan tetapi jawaban ini juga merupakan suatu jawaban yang juga memperingatkan terhadap bahaya penolakan terhadap undangan Allah yang menaruh anugerah yakni penghakiman eskatologis.

\section{Pengharapan Kesempurnaan Kerajaan}

Lukas mencatat ungkapan yang berbeda tentang pengharapan kedatangan kerajaan secara sempurna. Lukas 9:27 tertulis "sesungguhnya di antara orang yang hadir di sini ada yang tidak akan mati sebelum mereka melihat kerajaan Allah.” Prange menjelaskan bahwa cara untuk menyaksikan Kerajaan Allah dapat berarti banyak hal. Kerajaan Allah bisa berarti kehidupan yang kekal atau kedatangan Kristus yang kedua kalinya. ${ }^{25}$ Akan tetapi oleh karena memperhatikan ucapan Yesus terhadap murid-muridNya bahwa ada yang tidak akan merasakan kematian sebelum mereka menyaksikan Kerajaan Allah, maka pemikiran

\footnotetext{
${ }^{24}$ Prange, The People Bible: Luke, 165.

${ }^{25}$ Ibid.
}

perlu diarahkan kepada kepada pengungkapan Kerajaan Allah yang memiliki aspek kesegeraan. Ladd berpendapat bahwa ungkapan ini menegaskan bahwa kerajaan eskatologis akan datang dalam satu generasi kira-kira tiga puluh tahun pada waktu beberapa dari antara muridmurid itu masih hidup. ${ }^{26}$

Pengharapan kesempurnaan kerajaan juga diimbangi dengan ungkapan-ungkapan lain yang lebih menekankan penundaan daripada kesegeraan. Lukas 19:11, 17:22; 18:1-8 merupakan laporan-laporan Lukas yang menandai aspek penundaan kerajaan itu. Lukas 19:11 contohnya, Lukas mencatat satu perumpamaan tentang seorang bangsawan yang pergi ke negeri yang jauh untuk dinobatkan menjadi raja dan kemudian kembali karena manusia menyangka bahwa kerajaan allah akan segera kelihatan. Lagi pada pasal 17:22, Lukas mencatat "akan datang waktunya kamu ingin melihat satu daripada hari-hari Anak manusia itu dan kamu tidak akan melihatnya."

Dengan memperhatikan laporan Petrus, Bock melihat bahwa penundaan itu sebenarnya membuktikan kesabaran dan hasrat Allah untuk menyelamatkan. ${ }^{27}$ Dari pengamatan ini, patut disimpulkan bahwa kesegeraan dan penundaan bukanlah menjadi "ketidakpastian" dalam memahami kedatangan kerajaan, namun kesegeraan dan penundaan dalam pengharapan akan kesempurnaan penggenapan janji itu justru memberikan peringatan rohani bahwa manusia harus siap dan siaga untuk menghadapi datangnya kerajaan Allah secara sempurna itu.

\section{KESIMPULAN}

Kekhasan Lukas dalam menguraikan pengajaran eskatologis memang menunjukan perbedaan dengan penulis-penulis Perjanjian Baru lainnya. Sebagaimana yang telah dijelaskan pada bagian pendahuluan bahwa tujuan utama Lukas adalah berfokus pada universalitas, dimana Allah sedang menggenapi janjiNya, melalui orang-orang khusus dan peristiwaperistiwa yang unik. Oleh karena itu, tidak

\footnotetext{
${ }^{26}$ Ladd, Teologi Perjanjian Baru.

${ }^{27}$ Bock, "Teologi Lukas-Kisah Para Rasul."
} 
mengherankan apabila fokus eskatologi Lukas ada pada pembenaran akhir terhadap orangorang kudus berdasarkan janji yang telah diucapkanNya secara universal.

Melalui kekhasan eskatologi itu, konsistensi janji Allah sangat terlihat dengan jelas melalui narasi yang berisi janji eskatologis, awal penggenapan dan juga pengharapan akan kesempurnaan penggenapan yang akan terjadi di masa yang akan datang. Janji eskatologis menjadi dasar dari sebuah pengharapan yang pasti, awal penggenapan menjadi pengingat bahwa sebagian janji apokaliptis itu telah sebagian tergenapi dan pengharapan kesempurnaan penggenapan itu akan menjadi penghiburan bagi setiap orang yang menanti-nantikan kedatanganNya dengan setia. Kesudahan dunia berarti penebusan yang terakhir, pembebasan yang terakhir dari semua kejahatan yang berlangsung di dunia ini: dosa manusia, kematian dan kuasa dari kejahatan Iblis. Untuk suatu alasan yang tepat Lukas telah mencatat kekhasan eskatologinya sehingga memberi dorongan bagi orang percaya menadahkan pengharapan apabila tanda tanda akhir zaman ini sudah mulai terungkap.

\section{KEPUSTAKAAN}

Barclay, William. Introduction to the Three Gospels. Philadelphia: The Wesminster Press, 1975.

Bock, Darrell L. "Luke." In Baker Exegetical Commentary on the New Testament. Grand Rapids: Baker Books, 1996.

—. "Teologi Lukas-Kisah Para Rasul." In A Biblical Theology of the New Testament, edited by Darrell L. Bock and Zuck. Roy B. Malang: Gandum Mas, 2011.

Bond, John. The Gospel According to St. Luke. London: Macmillan, 1890.

Bruce, F.F. "Lukas." In Tafsiran Alkitab Masa Kini 3, edited by Donald Guthrie. Jakarta: Yayasan Komunikasi Bina Kasih, 2003.

—. Ucapan Yesus Yang Sulit. Malang: SAAT, 2001.

Enss, Paul. The Moody Handbook of Theology. Malang: SAAT, 2004.
Friberg, Barbara, Timothy Friberg, and Neva F. Miller. Analytical Lexicon of The New Testament. Grand Rapids: Baker Books, 2000.

Hendriksen, William, and Simon J. Kistemaker. "Exposition of the Gospel According to Luke." In New Testament Commentary. Grand Rapids: Baker Books, 2001.

Henning, Bruce. Matthew's Non-Messianic Mapping of Messianic Texts. BRILL, 2021. https://brill.com/view/title/58861.

Ladd, George E. Teologi Perjanjian Baru. Bandung: Kalam Hidup, 2017.

Morris, Leon. Teologi Perjanjian Baru. Malang: Gandum Mas, 2001.

Prange, Victor. The People Bible: Luke. Milwaukee: Northwestern Publising House, 1994.

Talbert, Charles H. Reading Act: Macon: Smyth \& Helwys Publishing, 2005. 